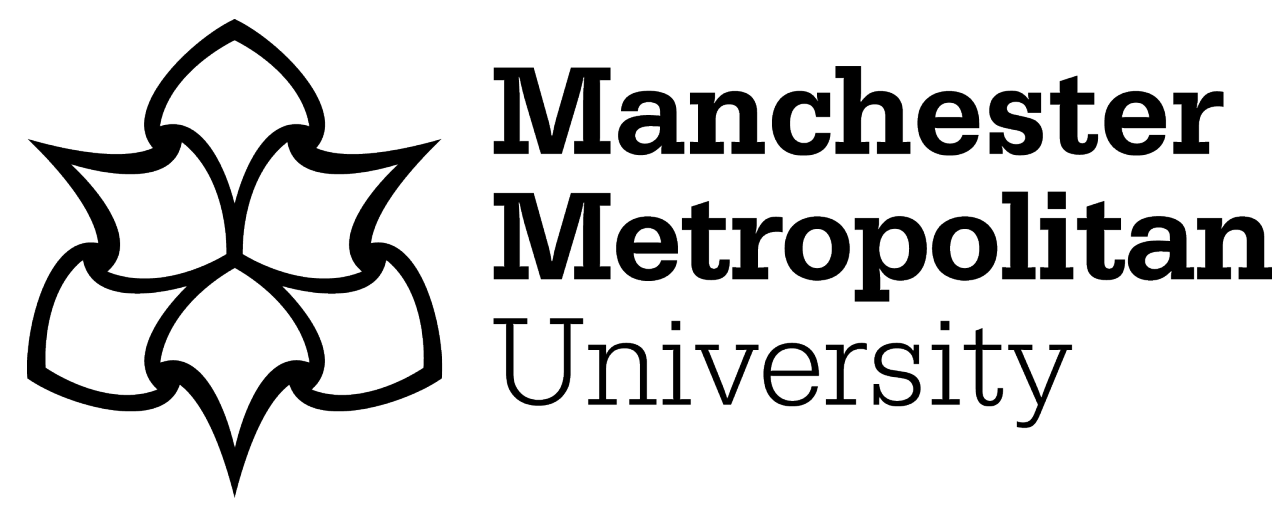

Barbanti, AM, Anholon, R, Rampasso, IS, Martins, VWB, Quelhas, OLG and Leal Filho, W (2022) Sustainable procurement practices in the supplier selection process: an exploratory study in the context of Brazilian manufacturing companies. Corporate Governance (Bingley), 22 (1). pp. 114-127. ISSN 1472-0701

Downloaded from: https://e-space.mmu.ac.uk/628516/

Version: Accepted Version

Publisher: Emerald

DOI: https://doi.org/10.1108/CG-10-2020-0481

Usage rights: Creative Commons: Attribution-Noncommercial 4.0

Please cite the published version 


\title{
Sustainable procurement practices in supplier selection process: an exploratory study in the context of Brazilian manufacturing companies
}

\author{
Corporate Governance (Bingley) 01 Jan 2021 \\ http://doi.org/10.1108/CG-10-2020-0481
}

Barbanti, Alex Moisés ${ }^{\mathrm{a}}$; Anholon, Rosley ${ }^{\mathrm{a}}$; Rampasso, Izabela Simonª,

Martins, Vitor W. B ${ }^{\mathrm{a}, \mathrm{c}}$; Quelhas, Osvaldo L. G ${ }^{\text {d }}$, Leal Filho, Walter ${ }^{\mathrm{e}}$

${ }^{a}$ School of Mechanical Engineering, State University of Campinas. Mendeleyev Street, 200. Campinas, São Paulo, Brazil; ${ }^{b}$ PNPD/CAPES Program, Doctoral Program in Sustainable Management Systems, Federal Fluminense University. Passo da Pátria Street, 156. Niteroi, Rio de Janeiro, Brazil ${ }^{c}$ Department of Production Engineering, State University of Pará, Travessa Dr. Enéas Pinheriro, 2626. Belém, PA, Brazil; ${ }^{d}$ Master Program in Management Systems and Doctoral Program in Sustainable Management Systems, Federal Fluminense University, Brazil. Passo da Pátria Street, 156. Niterói, Rio de Janeiro, Brazil; ${ }^{e}$ Faculty of Life Sciences, Hamburg University of Applied Sciences, Ulmenliet 20, D-21033 Hamburg Germany.

*Correspondent author: izarampasso@gmail.com

\section{Data Availability Statement}

The data that support the findings of this study are available on request from the corresponding author, ISR. The data are not publicly available due to do not compromise the privacy of research participants.

\section{Acknowledgements}

This work was supported by the Coordenação de Aperfeiçoamento de Pessoal de Nível Superior - Brasil (CAPES) - Finance Code 001; process 88887.464433/2019-00;

Conselho Nacional de Desenvolvimento Científico e Tecnológico (CNPq) 
116438/2019-3; 307536/2018-1; and 305442/2018-0; and Universidade do Estado do Pará (UEPA) 626/18.

Purpose: This study aims to evaluate the adoption of sustainable procurement practices adopted by Brazilian manufacturing companies in supplier selection; additionally, it is aimed to understand which of these practices enable a better differentiation of the analysed companies.

Design/methodology/approach: A systematic literature review was performed to compose the theoretical base of this research. In addition, a detailed study of ISO 20400 standard was conducted. The guidelines of ISO 20400 were used as a base to structure a questionnaire used in a survey with professionals working in procurement sphere of manufacturing companies in Brazil. The data were analysed via frequency and CRITIC (Criteria Importance Through Intercriteria Correlation) method.

Findings: A moderate dispersion in the adoption level of sustainable procurement practices in supplier selection process of the manufacturing companies was observed; in practices associated with social aspects, the dispersion is greater. A negative issue to be highlighted is that almost $20 \%$ of analysed companies did not even considered in their supplier selection process if their candidates accomplish philanthropic activities, generate jobs in local community, and fulfil the Universal Declaration of Human Rights of United Nations (UN). Those two last practices are the ones with the best capacity to differ the companies in the sample.

Originality/value: There are few studies that focuses on understanding the adoption of sustainable procurement practices in manufacturing companies' supplier selection process. The main contribution of this study to the literature is to evidence that social requirements in supplier selection process are considered in a clear and well-structured form only by few Brazilian manufacturing companies. Despite the sample size, companies analysed in this research are prominent organizations in manufacturing sector. Thus, if this situation occurs in these companies, a more critical scenario will be evidenced in other organizations. This study has implication for practice and academy. For companies' managers, information present here can be used to debate the theme in the organizational context and the nine practices and scale can be used to perform a critical analysis of company's practices. For researchers, the information present here can be used as starting point for futures studies. 
Keywords: Sustainable Procurement; ISO 20400; Manufacturing Companies; Brazil.

\section{Introduction}

The need for maintenance and regeneration of global ecosystem has been increasingly evident due to the impacts caused by industrial activity (Fernando, 2012; McPhail, 2008). In this sense, sustainability is more and more present in new management models (Aray et al., 2020; Garetti and Taisch, 2012; Høgevold et al., 2015; Lenssen et al., 2014). The pressure provided by society, government, media, regulatory agencies and by direct and indirect customers, i.e. by companies stakeholders, has become even more relevant, leading companies to accomplish their responsible role towards the society (Crespin-Mazet and Dontenwill, 2012; Ghadge et al., 2019; Maignan et al., 2002; Meixell and Luoma, 2015; Nilsson, 2019; Stonebraker et al., 2009).

Emerge, in this context, the Triple-Bottom Line (TBL) concept (Elkington, 1998), according to which the enterprises must evaluate their actions in the environmental, economic and social spheres (Dyllick and Hockerts, 2002; Nursimloo et al., 2020; Padin et al., 2016; Dos Santos et al., 2014; Yun et al., 2019). According to Nijaki and Worrel (2012), the industrial politics need to be grounded on TBL concepts to achieve a truly sustainable economic progress worldwide. An important contribution for this occurred in 2015, when the United Nations (UN, 2015) published the 17 Sustainable Development Goals (SDGs) (Sajjad et al., 2018), as it is corroborated by Larson (2019). Three of these SDGs (SDG 8, 9 and 12) are directly related to companies' aspects (Johnston, 2016; Martins et al., 2020).

To achieve satisfactory results in the implementation of sustainable practices, it is necessary that companies to frequently evaluate and continually improve these practices (Borges et al., 2018; Eriksson and Svensson, 2016; Gutiérrez-Martínez and Duhamel, 2019; Kowszyk and Vanclay, 2020). For those who argue that sustainable practices generate only costs and do not provide positive returns to companies, it should be highlighted the work of Pullman et al. (2009), according to which the implementation of social and environmental practices generate improvements in performance, including costs reduction. Birkin et al. (2009) corroborate this perspective and evidence in their research that environmental and social politics are capable to positively impact the business costs. 
Focusing on manufacturing industry, there is a consensus among researchers that it presents activities that can generate great negative impacts on environment, caused by its level of energy consumption, discard of toxic residues (e.g. refrigerant oils, cutting oils, casts etc.) and raw material loss. Besides that, depending on the productive process under analysis, some tasks may present risks for workers health, causing problems related to social aspects (Garetti and Taisch, 2012). These issues are the reason for the sustainable manufacturing concept gain focus in recent years. According to Garetti and Taisch (Garetti and Taisch, 2012), sustainable manufacturing can be defined as

"the ability to smartly use natural resources for manufacturing, by creating products and solutions that, thanks to new technology, regulatory measures and coherent social behaviours, are able to satisfy economical, environ- mental and social objectives, thus preserving the environment, while continuing to improve the quality of human life",

being employed in many industrial processes, including the procurement process.

Over decades, few attention was given to sustainable procurement processes by manufacturing process managers (Ghadimi and Heavey, 2014). However, this reality has started changing when organizations realized that "companies are only as sustainable as the suppliers that compose their supply chains" (Krause et al., 2009, p. 21). This shows the increasing relevance of supply chain management for companies sustainability aspects (Yu, Zhao, et al., 2019) and, considering the role of suppliers selection in supply chain management (Kaviani et al., 2019; Yu, Zou, et al., 2019), sustainability aspects must also be considered in suppliers selection (Yu, Zhao, et al., 2019). In this sense companies are demanded to conduct integrated actions, instead of punctual ones. Thus, Sustainable Procurement (SP) process started to be structured by companies.

Two definitions of SP presented in this research, in general, contemplate the macro features presented by the academic literature. The first one defines SP as being "Sustainable procurement can be defined as the pursuit of sustainable development objectives through the purchasing and supply process" (Sciencedirect, 2012, p. 201); the second definition, from ISO 20400:2017 standard (ISO, 2017, pp. 7-8), describes SP as "procurement that has the most positive environmental, social and economic impacts possible over the entire life cycle".

Focusing on Brazilian manufacturing companies' reality and ISO 20400 practices, no information was found in the academic literature that shows if companies are 
considering sustainable requirements in structured form in supplier selection processes and if there are differences among practices adoption level. A clear research gap was evidenced and the following research questions were defined to guide this study: Do Brazilian manufacturing companies consider sustainable requirements in a structured form in their supplier selection process? Comparatively, are there differences among practices adoption level?

Beyond this introduction, the present article is composed by 4 more sections. Section 2 is dedicated to the theoretical foundation. Section 3 presents the adopted methodological procedures. Section 4 presents the results and its associated debates. Section 5 presents the conclusions and the final considerations. Lastly, the references are listed.

\section{Theoretical foundation}

Supplier Selection, Sustainable Procurement, and ISO 20400 standard

One of the pioneers and a relevant study on SP processes is the research of Maignan et al. (Maignan et al., 2002), in which the authors argue that buyer companies must define sustainable objectives, designate employees to implement actions towards these objectives, educate and supervise suppliers for processes compliance and manage communication with all stakeholders.

In general, SP processes guidelines adoption has shown beneficial for organizations. Among the gains, some examples can be mentioned: costs reduction (Carter, 2005), improvement on the company's reputation, reduction of stakeholders' pressure (Awaysheh and Klassen, 2010; Maignan et al., 2002), innovation incentive (Maignan et al., 2002), improvement on working conditions, greater transparency in negotiations and information among companies (Preuss, 2009), environmental impacts reduction by suppliers (Klassen and Vachon, 2009) and other benefits (Islam et al., 2017; Meehan and Bryde, 2011).

For achieving these benefits, however, many actions have to be developed, for example: improvement in communication management between buyer and supplier companies (Carter and Jennings, 2004; Meehan and Bryde, 2011), improvement in the alignment of environmental and social objectives established at the beginning of commercial transactions (Walker and Brammer, 2012), audit processes in suppliers that 
really work towards continuous improvement of activities (Awaysheh and Klassen, 2010), mutual cooperation (Meehan and Bryde, 2011), development of indicators capable to measure sustainable practices adoption in purchasing processes (Carter and Jennings, 2002), among other actions. According to Hollos et al. (2012) the development of those actions contribute for sustainability and make companies more competitive.

Several authors (Brammer and Walker, 2011; Carter and Jennings, 2004; CrespinMazet and Dontenwill, 2012; Delmonico et al., 2018; Giunipero et al., 2012; Walker and Brammer, 2009) argue that senior management support can enhance the results of SP processes. The cooperation between buyer and supplier companies often involves different cultures (Brammer and Walker, 2011; Galpin et al., 2015; Thomson and Jackson, 2007), with different levels of risks acceptance (Meehan and Bryde, 2011) and, consequently, negotiation and convincing skills are important.

To avoid information conflicts among companies and guarantee aligned guidelines in SP adoption, International Organization for Standardization (ISO) proposed in 2017 the standard 20400. This standard presents sustainable procedures to procurement processes, based on ISO 26000:2010 standard, and it cannot be certified by companies (ISO, 2017).

Regarding its content, ISO 20400 presents initially a brief introduction of concepts associated to SP processes, i.e.: definitions, principles, main themes, motivators etc. The due diligence concept is highlighted, according to which companies must previously identify the possible impacts that purchasing processes might cause and define actions to mitigate them. In the sequence, ISO 20400 evidences relevant questions for an effective development of SP process, highlighting the importance of senior management support. It also provides and defines processes that must be implemented by organizations in order to guarantee sustainable practices in the mentioned processes (ISO, 2017). Lo-IaconoFerreira et al. (2018) refer to ISO 20400 as an example of SP guide to be followed by companies.

When analysing the academic literature, the lack of studies about the insertion of sustainability in procurement processes can be highlighted, when compared to other topics about the theme. Some of the research about the theme are presented.

Barraket (2020) and Loosemore and Reid (2019) conducted a study about the social procurement process in Australia and concluded that Australian organizations have 
started to give more attention to the subject. Ghadge et al. (2019) managed to discover influence patterns from stakeholders and from geographic localization along the supply chain in the SP processes of large companies. They found that sustainable practices are greater adopted by suppliers closer to the final customer, the geographic localization little influences the adoption of sustainable guidelines, and in sustainable suppliers' selection, the main influence factors are: environmental regulations, green procurement and quality of acquired products. Harris and Divakarla (2017), in their turn, cite the use of ecolabels as a manner to support the SP.

Kaur and Singh (2019) proposed an SP process model capable to unite qualitative and quantitative criteria, making possible for a company to improve its selection among several suppliers. Lastly, Ghadge et al. (2019) and Mcmurray et al. (2014), in their research, argue that companies are more prone to pursue environmental goals in SP processes. Meehan and Bryde (2011) and Oruezabala and Rico (2012) corroborate with this argument and consider that the reason for this is related to the greater visibility of these actions for companies customers.

The information mentioned reinforces the research gap presented in the introduction section and the research questions associated (Do Brazilian manufacturing companies consider sustainable requirements in a structured form in their supplier selection process? Comparatively, are there differences among practices adoption?) In addition, it is possible to verify that in some studies carried out with companies from other countries, social requirements in sustainable supplier selection are less adopted when compare to other requirements. Thus, this research focuses on better understanding this situation for Brazilian manufacturing companies' reality.

\section{Methodological Procedures}

The development of this research was composed by four phases. Figure 1 presents these phases and the next paragraphs detail them.

\section{Figure 1 position.}

The first phase was characterized by a bibliographic research, which enabled a greater understanding on ISO 20400 standard guidelines and sustainable practices in supplier selection processes related literature. The search for articles was performed in the following scientific databases: Emerald Insight, Scopus, Science Direct, Wiley and 
Taylor and Francis. The terms used for this search were: "sustainable procurement", "sustainable purchase"; "ISO 20400"; "supply chain management", "supplier selection" and "sustainable supplier selection". Different combinations among these terms were used. It was possible to evidence, as showed in section two, that sustainable practices in supplier selection process of Brazilian manufacturing companies is a little studied theme, justifying in this case an exploratory research.

The second phase was characterized by the research protocol definition, highlighting specially the structuration of the questionnaire used in the survey. The first part of the questionnaire was dedicated for respondents' characterization and the second part focused on the analysis of the sustainable practices developed by the studied companies in their supplier selection. Based on ISO 20400 standard, nine sustainable practices plausible to be applied in supplier selection were structured. These practices are presented in Table 1.

\section{Table 1 position.}

Research participants needed to evaluate each practice of Table 1 based on the reality of their companies, through an evolutive grades ranging from 0 to 10 . These grades were allocated in ranges as showed in Table 2. It should be highlighted that the existence of two grades in most of the ranges aimed to provide for the respondents a better alignment of their answers. The use of a scale to measure the level of sustainable practices adoption in supplier selection processes was carried out to allow comparisons among companies, even in an exploratory form. We believe that the use of this scale reduces subjectivities.

\section{Table 2 position.}

It is important to highlight that a pilot test of the questionary was performed with some professors and managers in other to identify possible improvement opportunities. In addition, we emphasize that before survey execution, the research project was submitted and approved by an ethics committee (CAAE: 18829419.1.0000.5405).

The third phase focused on searching respondents within the profile deserved through the professional social networks. A total of 405 professionals were listed. After a more detailed screening, 240 of those fulfilled the criteria required to participate of this research. The invites were sent for all of them and 31 valid questionnaires were obtained, 
which represents a response rate of $13.3 \%$. The survey was conducted online, through Google Forms platform.

The respondents work in manufacturing companies of the following segments: agricultural, industrial automation, auto parts, aviation, home appliances, elevators, packaging, high pressure equipment, vehicle assembler, etc. Regarding the company's size, most of them are classified as large companies when considered the number of employees (one of the criteria used in Brazil to classify organizations) and are located in the southeaster region of the country.

The fourth phase corresponded to data analysis, presentation of the results and debates about them. Initially, it was performed a frequency analysis to identify the amount of companies allocated in the different score ranges of each sustainable practice presented in Table 1.

In the sequence, aiming to identify the practices which better permit differentiate the samples companies, the CRITIC (Criteria Importance Through Intercriteria Correlation) method was used. This method seeks to define weights for the analysed variables and, thereby, define those with greater influence in determined analysis (Adalı and Işık, 2017; Diakoulaki et al., 1995).

The first step to evaluate the studied variables consist in normalize all the values obtained for each practice, through Equation (1) (Adalı and Işık, 2017; Diakoulaki et al., 1995). For this normalization, it is needed to identify the maximum and minimum scores attributed for each criterion (practice).

$$
\bar{P}_{i}=\frac{P_{i}-P_{\min }}{P_{\max }-P_{\min }} \quad(\text { Equation } 1)
$$

In which,

$i$ is the score to be evaluated within a pre-defined parameter (between 1 and 9);

Pmin is the lowest value of the evaluated parameter;

Pmax is the maximum value.

In the sequence, the standard deviation $\left(\sigma_{j}\right)$ of normalized values for each studied criterion must be determined, in this research, for each sustainable practice considered plausible to be adopted in supplier selection process. The result is a vector of standard deviations. 
The third step of the method is characterized by structuring a symmetric matrix $(\mathrm{N} \mathrm{x}$ $\mathrm{N}$ ) in which the elements represent the correlation between studied parameters (Adali and Iş1k, 2017; Diakoulaki et al., 1995), in this case, correlation between the practices.

The next step is to determine the quantity of information generated by each criteria $\left(I_{j}\right)$ (Adalı and Iş1k, 2017; Diakoulaki et al., 1995). For this, initially it is necessary to subtract the value 1 from each element of the linear correlation's symmetric matrix $(\mathrm{N} x$ N) and, posteriorly, the sum value is calculated for each line. The obtained value multiplied by the standard deviation $\left(\sigma_{j}\right)$ of each practice, previously calculated, will provide the criterion information quantity, as presented in Equation 2.

$$
I_{j}=\sigma_{j} \cdot \sum_{j=1}^{N}\left(1-c_{j}\right)(\text { Equation } 2)
$$

In which,

$\mathrm{j}$ is equivalent to the chosen parameter for the analysis, variating from 1 to 9 , in this case.

To determine the weight of criteria (studied practice) in percentage, it is necessary to divide the obtained information quantity for each of criterion by the summation of all information quantity, as presented in Equation 3 (Adalı and Işık, 2017; Diakoulaki et al., 1995).

$$
W_{j}=\frac{I_{j}}{\sum_{k=1}^{N} I_{k}} \quad(\text { Equation } 3)
$$

In which,

$\mathrm{k}$ is the defined parameters, variating from 1 to 9 .

Once the results were obtained, they were debated considering the context of Brazilian manufacturing companies and the existing literature.

\section{Results and discussion}

As highlighted in the previous section, the first analysis made was the frequencies study of companies allocated in each evolutive range for each practice. These frequency values are presented in Table 3. 


\section{Table 3 position.}

Some of the presented values need to be detailed. Regarding the percentage distributions of companies in practices P3 (Analysis of social assistance - philanthropies - campaigns realization to the local community by supplier candidates) and P6 (Analysis of Universal Declaration of Human Rights and other documents related to UN fulfilment by supplier candidates), they highlight a negative aspect: the quantity of companies that do not adopt these practices (more than $22 \%$ of the analysed companies scored zero for these practices). Close to them in percentual terms is the practice P4 (Analysis of job generation on the local community by supplier candidates). These three mentioned practices are directly involved with social aspects and, considering the Elkington (1998) concept of sustainability, which defines the three sustainable pillars: economic, environmental and social; these findings highlight an alert point. Social requirements in supplier selection process are considered in a clear and well-structured form only by few companies (thus, existing a lot of heterogeneity).

On the other hand, the following practices presented a positive outcome: P2 (Existence analysis and diffusion of practices associated to anticorruption and transparency by supplier candidates); P5 (Analysis of labour laws fulfilment (Brazilian CLT $=$ consolidation of labour laws) by supplier candidates) and P9 (Analysis of existence and adoption of prevention of health and safety of customers politics by supplier candidates). Around $60 \%$ of the companies are concentrated in the last (and highest) evolutive range. In this range, companies adopt the practice, have structured procedures for analysis and constantly debate and review them aiming continuous improvement.

In relation to the existence of structured procedures for each practice (from score 7 to 10), the authors of this article understand that the existence of them indicates a dividing line between companies, since for structuring them, it was necessary some debate level and questioning by company's workers. Considering the exposed, an interesting analysis that can be made is characterized by dividing the sample between companies that do not have structured procedures for using the practice in supplier selection and those that have it even if it is in a first version that needs revisions and improvements. Table 4 presents the frequencies considering this analysis.

\section{Table 4 position.}


When analysed the practices P3, P4, P6 and P7 (all related to sustainability's social character), it is evidenced that most of the analysed companies do not adopt them or, when they adopt, they do not use structured procedures. Among those practices with the highest percentage of companies presenting structured processes, P2 and P5 (both related to legal issues) are highlighted.

Once analysed the frequency distribution by evolutive ranges and those that stand out, negatively or positively, the obtained results by the CRITIC (Criteria Importance Through Intercriteria Correlation) method are presented. It is important to remind that the application of this method aimed to identify the practices that best differentiate the analysed companies.

The first step corresponded to the normalization of the scores assigned by the respondents. For this, it was necessary to identify the maximum and minimum scores for each practice. The Equation 1 was used and the normalized values are presented in Table 5. In the end of this table, the values of the standard deviation $\left(\sigma_{j}\right)$ for each practice studied are presented.

Table 5 position.

In the next step, it was performed the process to determine the amount of information generated by each practice $\left(I_{j}\right)$. For this, Equation 2 was used. The symmetric matrix $(9 \times 9)$ of liner correlations $\left(c_{j}\right)$ between practices was calculated and, in sequence, value " 1 " was subtracted, obtaining the term $\left(1-c_{j}\right)$. Posteriorly, the lines were summed to obtain the term $\sum_{j=1}^{N}\left(1-c_{j}\right)$. The results of these calculations are presented on Table 6 .

\section{Table 6 position.}

The obtained values from $\sum_{j=1}^{N}\left(1-c_{j}\right)$ presented in Table 6 were multiplied by the standard deviation $\left(\sigma_{j}\right)$ (presented in Table 5) to obtain the amount of information of each practice $\left(I_{j}\right)$. To better facilitate the comprehension of the importance of each practice in terms of the capacity to differentiate the analysed companies, the values were also 
presented in percentages. The calculations were performed using Equation 3. The calculus memorial is presented in Table 7.

\section{Table 7 position.}

Considering the existence of 9 practices, if they presented the same importance on the companies' differentiation, the evidenced weight would be $11.1 \%$. However, two practices are over this percentage (P6 and P4) and one with the lowest weight (P1).

Regarding practice P1 (Existence and diffusion analysis of environmental preservation policies by supplier candidates), it is the one that least allows to differentiate the companies in the sample. This fact might be comprehended by the fact that manufacturing companies traditionally follow environmental standards along with quality and occupational health and safety standards. This finding does not mean that it is an irrelevant item, far from it, but by the fact that correlates with other practices and/or present more homogeneous pattern of use by companies' part, it differentiates less the analysed enterprises. This information is in accordance with several authors (Ghadge et al., 2019; McMurray et al., 2014; Meehan and Bryde, 2011; Oruezabala and Rico, 2012), when affirming that companies tend to focus on environmental aspects as a way to increase their visibility to customer, which result in a major homogeneity of actions practiced in this sense.

On the other hand, the practices P4 (Analysis of job generation in the local community by supplier candidates) and P6 (Analysis of compliance with the Universal Declaration of Human Rights and other documents related to UN by supplier candidates) are those more capable to differ the analysed companies. Due to the higher heterogeneity in these practices adoption and/or the correlation is less intense with other practices that do not directly have a social character, they stand out with a better capacity for differentiation. This information can be an important insight for future research related to the use of sustainable criteria for suppliers selection, since Luthra et al. (2017), argue that these criteria are few emphasized by researchers.

\section{Conclusion and final considerations}

The main conclusion of this study is that there is a moderate dispersion among the analysed Brazilian manufacturing companies when considered sustainable practices 
adoption in supplier selection. Comparatively, a greater heterogeneity is observed in social practices and they are the less adopted in a well-structured form by most of the companies.

Regarding social practices, a negative point to be highlighted is the non-utilization of three of them by approximately $20 \%$ of the companies studied in their evaluation process of supplier candidates. These practices are: P3 (Analysis of social assistance (philanthropies) campaigns realization to the local community by supplier candidates); P4 (Analysis of job generation in the local community by supplier candidates) and P6 (Analysis of compliance with the Universal Declaration of Human Rights and other documents related to UN by supplier candidates). Additionally, it should be mentioned that P4 and P6 are the practices that have the greatest capacity to differ the analysed companies. Although the sample is composed of a small number of companies, they are prominent manufacturing organizations in Brazil. It is possible to infer that if in this sample few companies adopt in a clear and well-structured form social requirements in supplier selection process, a more critical scenario will be evidenced in other organizations.

The main contribution of this study to the literature is to evidence the need of wellstructured social practices as a criterion used by Brazilian manufacturing companies when selecting their suppliers. This study has implication for practice and academy. For companies' managers, information present here can be used to debate the theme in the organizational context and the nine practices (table 1) and scale (table 2) can be used to performed a critical analysis on their company's practices. For researchers, the information present here can be used as starting point for futures studies.

Logically, the participation of 31 professionals who reported the practices adoption level of their companies in supplier selection process and the choice of the method to analyse data can be considered study limitations, however, we remember that this study has an exploratory character. As mentioned in the previously paragraph, the companies analysed are prominent manufacturing organizations in Brazil and if the adoption of social requirements in the selection of suppliers is not widely adopted by most of them, a more critical scenario can be expected in the others. 
For future research, it is recommended the realization of case studies with companies allocated in the last evolutive range, i.e. they adopt the analysed practice and there are procedures structured for analysis and these procedures are constantly debated and reviewed aiming continuous improvement.

\section{References}

Adalı, E.A. and Işık, A.T. (2017), "Critic and Maut Methods for the Contract Manufacturer Selection Problem”, European Journal of Multidisciplinary Studies, Vol. 5 No. 1, p. 93.

Aray, Y., Veselova, A., Knatko, D. and Levchenko, A. (2020), "Drivers for adoption of sustainability initiatives in supply chains of large Russian firms under environmental uncertainty", Corporate Governance (Bingley), No. July, available at:https://doi.org/10.1108/CG-02-2020-0048.

Awaysheh, A. and Klassen, R.D. (2010), "The impact of supply chain structure on the use of supplier socially responsible practices", International Journal of Operations and Production Management, Vol. 30 No. 12, pp. 1246-1268.

Barraket, J. (2020), “The Role of Intermediaries in Social Innovation: The Case of Social Procurement in Australia", Journal of Social Entrepreneurship, Routledge, Vol. 11 No. 2, pp. 194-214.

Birkin, F., Polesie, T. and Lewis, L. (2009), “A new business model for sustainable development: An exploratory study using the theory of constraints in nordic organizations", Business Strategy and the Environment, Vol. 18 No. 5, pp. 277290.

Borges, M.L., Anholon, R., Cooper Ordoñez, R.E., Quelhas, O.L.G., Santa-Eulalia, L.. and Leal Filho, W. (2018), “Corporate Social Responsibility (CSR) practices developed by Brazilian companies: an exploratory study", International Journal of Sustainable Development \& World Ecology, Taylor \& Francis, Vol. 25 No. 6, pp. $509-517$.

Brammer, S. and Walker, H. (2011), "Sustainable procurement in the public sector: An international comparative study", International Journal of Operations and Production Management, Vol. 31 No. 4, pp. 452-476. 
Carter, C.R. (2005), "Purchasing social responsibility and firm performance: The key mediating roles of organizational learning and supplier performance", International Journal of Physical Distribution and Logistics Management, Vol. 35 No. 3, pp. 177-194.

Carter, C.R. and Jennings, M.M. (2002), "Social responsibility and supply chain relationships", Transportation Research Part E: Logistics and Transportation Review, Vol. 38 No. 1, pp. 37-52.

Carter, C.R. and Jennings, M.M. (2004), "the Role of Purchasing in Corporate Social Responsibility: a Structural Equation Analysis”, Journal of Business Logistics, Vol. 25 No. 1, pp. 145-186.

Crespin-Mazet, F. and Dontenwill, E. (2012), "Sustainable procurement: Building legitimacy in the supply network", Journal of Purchasing and Supply Management, Vol. 18 No. 4, pp. 207-217.

Delmonico, D., Jabbour, C.J.C., Pereira, S.C.F., de Sousa Jabbour, A.B.L., Renwick, D.W.S. and Thomé, A.M.T. (2018), "Unveiling barriers to sustainable public procurement in emerging economies: Evidence from a leading sustainable supply chain initiative in Latin America", Resources, Conservation and Recycling, Elsevier, Vol. 134 No. March, pp. 70-79.

Diakoulaki, D., Mavrotas, G. and Papayannakis, L. (1995), "Determining objective weights in multiple criteria problems: The critic method", Computers and Operations Research, Vol. 22 No. 7, pp. 763-770.

Dyllick, T. and Hockerts, K. (2002), "Beyond the business case for corporate sustainability”, Business Strategy and the Environment, Vol. 11 No. 2, pp. 130141.

Elkington, J. (1998), “Triple bottom line.pdf”, Environmental Quality Management, Vol. 8 No. 1, pp. 37-51.

Eriksson, D. and Svensson, G. (2016), “A balance model of theoretical sustainability framework and propositions", Corporate Governance (Bingley), Vol. 16 No. 1, pp. 21-34.

Fernando, R. (2012), “Sustainable globalization and implications for strategic corporate 
and national sustainability", Corporate Governance (Bingley), Vol. 12 No. 4, pp. $579-589$.

Galpin, T., Whittington, J.L. and Bell, G. (2015), "Is your sustainability strategy sustainable? Creating a culture of sustainability", Corporate Governance (Bingley), Vol. 15 No. 1, pp. 1-17.

Garetti, M. and Taisch, M. (2012), "Sustainable manufacturing: trends and research challenges", Production Planning \& Control, Vol. 23 No. 2-3, pp. 83-104.

Ghadge, A., Kidd, E., Bhattacharjee, A. and Tiwari, M.K. (2019), "Sustainable procurement performance of large enterprises across supply chain tiers and geographic regions", International Journal of Production Research, Taylor \& Francis, Vol. 57 No. 3, pp. 764-778.

Ghadimi, P. and Heavey, C. (2014), "Sustainable supplier selection in medical device industry: Toward sustainable manufacturing”, Procedia CIRP, Elsevier B.V., Vol. 15, pp. $165-170$.

Giunipero, L.C., Hooker, R.E. and Denslow, D. (2012), "Purchasing and supply management sustainability: Drivers and barriers", Journal of Purchasing and Supply Management, Elsevier, Vol. 18 No. 4, pp. 258-269.

Gutiérrez-Martínez, I. and Duhamel, F. (2019), "Translating sustainability into competitive advantage: the case of Mexico's hospitality industry", Corporate Governance (Bingley), Vol. 19 No. 6, pp. 1324-1343.

Harris, K. and Divakarla, S. (2017), "Supply Chain Risk to Reward: Responsible Procurement and the Role of Ecolabels", Procedia Engineering, Elsevier B.V., Vol. 180, pp. 1603-1611.

Høgevold, N.M., Svensson, G., Klopper, H.B., Wagner, B., Valera, J.C.S., Padin, C., Ferro, C., et al. (2015), "A triple bottom line construct and reasons for implementing sustainable business practices in companies and their business networks", Corporate Governance (Bingley), Vol. 15 No. 4, pp. 427-443.

Hollos, D., Blome, C. and Foerstl, K. (2012), "Does sustainable supplier co-operation affect performance? Examining implications for the triple bottom line", International Journal of Production Research, Vol. 50 No. 11, pp. 2968-2986. 
Islam, M.M., Turki, A., Murad, M.W. and Karim, A. (2017), "Do sustainable procurement practices improve organizational performance?", Sustainability (Switzerland), Vol. 9 No. 12, pp. 1-17.

ISO. (2017), ISO 20400: Sustainable Procurement - Guidance, Geneva.

Johnston, R.B. (2016), "Arsenic and the 2030 Agenda for sustainable development", Arsenic Research and Global Sustainability - Proceedings of the 6th International Congress on Arsenic in the Environment, AS 2016, pp. 12-14.

Kaur, H. and Singh, S.P. (2019), "Flexible dynamic sustainable procurement model", Annals of Operations Research, Springer US, Vol. 273 No. 1-2, pp. 651-691.

Kaviani, M.A., Karbassi Yazdi, A., Ocampo, L. and Kusi-Sarpong, S. (2019), “An integrated grey-based multi-criteria decision-making approach for supplier evaluation and selection in the oil and gas industry", Kybernetes, Vol. 49 No. 2 , pp. 406-441.

Klassen, R.D. and Vachon, S. (2009), “COLLABORATION AND EVALUATION IN THE SUPPLY CHAIN: THE IMPACT ON PLANT-LEVEL ENVIRONMENTAL INVESTMENT", Production and Operations Management, Vol. 12 No. 3, pp. $336-352$.

Kowszyk, Y. and Vanclay, F. (2020), "The possibilities and limitations regarding the use of impact evaluation in corporate social responsibility programs in Latin America", Corporate Governance: The International Journal of Business in Society, Vol. ahead-of-p No. ahead-of-print, available at:https://doi.org/10.1108/CG-01-2020-0038.

Krause, D.R., Vachon, S. and Klassen, R.D. (2009), “SPECIAL TOPIC FORUM ON SUSTAINABLE SUPPLY CHAIN MANAGEMENT: INTRODUCTION AND REFLECTIONS ON THE ROLE OF PURCHASING MANAGEMENT”, Journal of Supply Chain Management, Vol. 45 No. 4, pp. 18-25.

Larson, P.D. (2019), "Corruption, gender inequality and logistics performance”, International Journal of Logistics Management, Vol. 31 No. 2, pp. 381-397.

Lenssen, J.J., Dentchev, N.A. and Roger, L. (2014), "Sustainability, Risk management and governance: towards an integrative approach", Corporate Governance 
(Bingley), Vol. 14 No. 5, pp. 670-684.

Lo-Iacono-Ferreira, V.G., Capuz-Rizo, S.F. and Torregrosa-López, J.I. (2018), “Key Performance Indicators to optimize the environmental performance of Higher Education Institutions with environmental management system - A case study of Universitat Politècnica de València”, Journal of Cleaner Production, Vol. 178, pp. 846-865.

Loosemore, M. and Reid, S. (2019), “The social procurement practices of tier-one construction contractors in Australia", Construction Management and Economics, Routledge, Vol. 37 No. 4, pp. 183-200.

Luthra, S., Govindan, K., Kannan, D., Mangla, S.K. and Garg, C.P. (2017), “An integrated framework for sustainable supplier selection and evaluation in supply chains", Journal of Cleaner Production, Elsevier Ltd, Vol. 140, pp. 1686-1698.

Maignan, I., Hillebrand, B. and McAlister, D.T. (2002), "Managing socially Responsible buying: How to integrate non-economic criteria into the purchasing process", European Management Journal, Vol. 20 No. 6, pp. 641-648.

Martins, V.W.B., Rampasso, I.S., Siltori, P.F.S., Cazeri, G.T., Anholon, R., Quelhas, O.L.G. and Leal Filho, W. (2020), "Contributions from the Brazilian industrial sector to sustainable development", Journal of Cleaner Production, Elsevier Ltd, Vol. 272, p. 122762.

Mcmurray, A.J., Islam, M., Siwar, C. and Fien, J. (2014), “Journal of Purchasing \& Supply Management Sustainable procurement in Malaysian organizations : Practices , barriers and opportunities", Journal of Purchasing and Supply Management, Elsevier, Vol. 20 No. 3, pp. 195-207.

McMurray, A.J., Islam, M.M., Siwar, C. and Fien, J. (2014), "Sustainable procurement in Malaysian organizations: Practices, barriers and opportunities", Journal of Purchasing and Supply Management, Elsevier, Vol. 20 No. 3, pp. 195-207.

McPhail, K. (2008), "Global governance challenges in industry sectors and supply chains: Contributing to sustainable development through multi-stakeholder processes: Practical steps to avoid the 'resource curse"', Corporate Governance, Vol. 8 No. 4, pp. 471-481. 
Meehan, J. and Bryde, D. (2011), "Sustainable procurement practice", Business Strategy and the Environment, Vol. 20 No. 2, pp. 94-106.

Meixell, M.J. and Luoma, P. (2015), "Stakeholder pressure in sustainable supply chain management: A systematic review", International Journal of Physical Distribution and Logistics Management, Vol. 45 No. 1, pp. 69-89.

Nijaki, L.K. and Worrel, G. (2012), "Procurement for sustainable local economic development", International Journal of Public Sector Management, Vol. 25 No. 2, pp. 133-153.

Nilsson, F.R. (2019), “A complexity perspective on logistics management: Rethinking assumptions for the sustainability era", International Journal of Logistics Management, Vol. 30 No. 3, pp. 681-698.

Nursimloo, S., Ramdhony, D. and Mooneeapen, O. (2020), "Influence of board characteristics on TBL reporting", Corporate Governance (Bingley), Vol. 20 No. 5, pp. 765-780.

Oruezabala, G. and Rico, J.C. (2012), "The impact of sustainable public procurement on supplier management - The case of French public hospitals", Industrial Marketing Management, Elsevier Inc., Vol. 41 No. 4, pp. 573-580.

Padin, C., Ferro, C., Wagner, B., Valera, J.C.S., Høgevold, N.M. and Svensson, G. (2016), "Validating a triple bottom line construct and reasons for implementing sustainable business practices in companies and their business networks", Corporate Governance (Bingley), Vol. 16 No. 5, pp. 849-865.

Preuss, L. (2009), “Addressing sustainable development through public procurement: The case of local government", Supply Chain Management, Vol. 14 No. 3, pp. $213-223$.

Pullman, M.E., Maloni, M.J. and Carter, C.R. (2009), "Food for thought: Social versus environmental sustainability practices and performance outcomes", Journal of Supply Chain Management, Vol. 45 No. 4, pp. 38-54.

Sajjad, A., Jillani, A. and Raziq, M.M. (2018), "Sustainability in the Pakistani hotel industry: an empirical study", Corporate Governance (Bingley), Vol. 18 No. 4, pp. $714-727$. 
Dos Santos, M.A.O., Svensson, G. and Padin, C. (2014), “Implementation, monitoring and evaluation of sustainable business practices: framework and empirical illustration", Corporate Governance (Bingley), Vol. 14 No. 4, pp. 515-530.

Sciencedirect, S. (2012), “Journal of Purchasing \& Supply Management Sustainable procurement : Past, present and future", Journal of Purchasing and Supply Management, Vol. 18, pp. 201-206.

Stonebraker, P.W., Goldhar, J. and Nassos, G. (2009), "Weak links in the supply chain: Measuring fragility and sustainability", Journal of Manufacturing Technology Management, Vol. 20 No. 2, pp. 161-177.

Thomson, J. and Jackson, T. (2007), "Sustainable procurement in practice: Lessons from local government", Journal of Environmental Planning and Management, Vol. 50 No. 3, pp. 421-444.

UN. (2015), "Sustainable Development Goals (SDGs)", available at: https://sustainabledevelopment.un.org/sdg4 (accessed 2 May 2019).

Walker, H. and Brammer, S. (2009), "Sustainable procurement in the United Kingdom public sector", Supply Chain Management, Vol. 14 No. 2, pp. 128-137.

Walker, H. and Brammer, S. (2012), “The relationship between sustainable procurement and e-procurement in the public sector", International Journal of Production Economics, Elsevier, Vol. 140 No. 1, pp. 256-268.

Yu, C., Zhao, W. and Li, M. (2019), “An integrated sustainable supplier selection approach using compensatory and non-compensatory decision methods", Kybernetes, Vol. 48 No. 8, pp. 1782-1805.

Yu, C., Zou, Z., Shao, Y. and Zhang, F. (2019), “An integrated supplier selection approach incorporating decision maker's risk attitude using ANN, AHP and TOPSIS methods", Kybernetes, Vol. 49 No. 71501187, pp. 2263-2284.

Yun, G., Yalcin, M.G., Hales, D.N. and Kwon, H.Y. (2019), "Interactions in sustainable supply chain management: a framework review", International Journal of Logistics Management, Vol. 30 No. 1, pp. 140-173. 
I 
